\title{
An Integrative Model to Explain the Ability to Commercialize Innovations: Linking Networks, Absorptive Capacity, Ambidexterity and Environmental Factors
}

\author{
Avimanyu Datta \\ Department of Management \& Quantitative Methods, College of Business, Illinois State University \\ Campus Box 5580, Normal, IL 61790-5580, USA \\ Tel: +1-309-438-5701Ｆax:+1-309-438-8201Ｅ-mail: avimanyu.datta@gmail.com
}

Received: April 4, $2011 \quad$ Accepted: April 27, $2011 \quad$ doi:10.5430/jms.v2n2p2

\begin{abstract}
The ability to commercialize innovations is central to firm survival and success and, despite research on parts of the process, it remains somewhat obscure. We explore the literature to build an integrative model of the antecedents, mediators, and moderators of commercialization. We identify intra- and inter-organizational networks and the resources they embody as key drivers of the ability to commercialize. Absorptive capacity and ambidexterity act as mediators on that relationship. Further, environmental turbulence, munificence, and complexity moderate the relationship between networks and absorptive capacity and ambidexterity. We generate propositions on these relationships for empirical testing and further theoretical insight.
\end{abstract}

Keywords: Commercialization of Innovations, Ambidexterity, Absorptive Capacity, Networks

\section{Introduction}

It has been argued that successful commercialization of innovation is necessary in order for firms to be competitive (Nevens, Summe \& Uttal, 1990). For example, Nokia and Sony-Ericsson, each successfully have introduced over seventy models of cellular phones in 2008, penetrating many available market niches with their portfolios. That pace of commercialization not only helps the innovators to be successful with introduced products but also raises barriers for existing and potential competitors. However, many new product launches are not successful - the list of failed commercializations includes everything from vitamin enriched sodas, smokeless cigarettes, to online bidding for groceries and gas, to failed automobile models. Scholars, not only have conjectured that successful commercialization of innovations is of strategic importance to firms (Nerkar \& Shane, 2007), but also is necessary to advance the economy (Cohen \& Levinthal, 1990; Eisenhardt \&Martin, 2000; Zahra \& Neilson, 2002; Sorensen \& Stuart, 2000). The ability to commercialize can help firms improve market penetration and dominance in existing markets, or create new markets, which contributes to the attainment of sustained leadership and firm longevity, which, in turn, positively impacts the health of the economy within which the firm operates (Wallsten, 2000; Lerner 1999; Salamenkaita, \& Salo, 2002). It therefore is no surprise that governments at nearly all levels attempt to mitigate market and other systemic failures to eliminate structural economic and industry-level rigidities. A better understanding of the successful commercialization of innovations is thus important at multiple levels.

There exists an emerging body of research that helps us understand which organizational characteristics correlate with a firm's ability to commercialize innovation. It has been suggested that the ability to commercialize innovations reflects a firm's capabilities (Damanpour 1991; Dourgerty \& Hardy, 1996; McGrath et al., 1996; Pennings \& Harianto, 1992, Teece, Pisano \& Shuen, 1997), its human resource practices (Nerkar, McGrath \& Macmillan, 1996; Scott \& Bruce, 1994), the nature of the top management team (Bantel \& Jackson, 1989; Howell \& Higgins, 1990), and the external environment within which the firm operates (Abrahamson \& RosenKopf, 1993; Keats \& Hitt, 1988; Milliken, 1987; Wade, 1996). Much of the cited literature, however, has treated innovation and its commercialization as the same construct. In fact, commercialization in many cases was assumed. While we agree that innovation characteristics are a necessary component of future market success, innovation per se is not sufficient to ensure that success. Instead, innovations generally lead to market success through the process of commercialization (Drucker, 1985). While this growing body of work undoubtedly contributes to our understanding of successful commercialization, it remains that a dedicated model of the factors affecting commercialization is still essential. 
Firms typically depend on products developed three to five years ago for large portions of their current sales. Correspondingly, they find themselves aiming three to five years in the future at a target that is both elusive and competitive in nature (Burgelman, Christensen \& Wheelwright, 2006; Grove, 1996). Additionally, globalization of markets has put more pressure on firms to commercialize innovations in order to fend off global competition, to expand into global markets, or both (Hamel \& Prahalad, 2002; Hamel \& Getz, 2004; Collin \& Porras, 1999; Huygens, Baden-Fuller, Van Den Bosh, Volberda, 2001; Huber, \& Glick, 1993; March 1991). Thus, the need to bring innovations to market successfully is greater than ever. Again, Nokia responded to this environmental stimulus with the introduction of over eighty models of cellular phones and Sony responded with fifty models of portable audio players, with no apparent end to innovative products from either firm, and the same is true for rapidly growing companies like Samsung, and LG. In addition to these global stimuli, other environmental factors such as rapid technological development simultaneously enhances and exacerbates the need for successful commercialization of innovation. Advances in information technology, and greater ease of use of these technologies, have led to shorter cycle times in developing new technology applications. These changes have resulted in greater process improvements and more efficient generation of new products and product changes (Brynjolfsson \& Mendelson, 1993; Gulati, Sawhney, \& Paoni, 2002), which has further increased the speed with which firms and their competitors need to innovate and commercialize.

The rest of this paper is organized as follows. It begins with a discussion of the dependent variable-the ability to commercialize innovations. Then, we concentrate on a discussion of antecedents and mediators to commercialization, including, networks, ambidexterity, and absorptive capacity. In the subsequent section we discuss the factors that moderate the influence of networks and resources on ambidexterity and absorptive capacity. To ease assimilation of the discussion, we include a table of definitions of our constructs (Table 1) and our theoretical model (Figure 1). We conclude with a discussion of the contributions and limitations of this work, as well as suggestions for future research.

$<$ Table 1 about here $>$

$<$ Figure 1 about here $>$

\section{Theoretical Model}

\subsection{Ability to Commercialize Innovation}

According to Burgelman, Christensen, \& Wheelwright (2006), the innovation process is defined as the combined activities leading to new, marketable products and services, or new product-delivery systems. As already noted, many scholars have combined innovation and commercialization within the same construct; for example, see Burgelman and colleagues (2006) who included the process of getting innovations to market within their definition of innovation. However, some have kept innovation and commercialization as separate and distinct constructs. Commercialization of innovation has been defined as the act or activities required for introducing an innovation to market (Kelm, Narayanan, \& Pinches, 1995; Narayanan et al., 2000; Nambison \& Sawhney, 2007; Andrew \& Sirkin, 2003; Kwak, 2002; Nerkar \& Shane, 2007). Nerkar \& Shane (2007) measured commercialization of innovation as the early indication of commercialization, and operationalized it as the first sale of a given product or service. Moore (1991; 2000), on the other hand, posited that when an innovation is introduced in the market, only technology enthusiasts will adopt it, and such enthusiasts comprise less than three percent of the market. Moore (2000) thus argued that the larger mainstream market is comprised of pragmatists and conservatives, and so a successful commercialization is one that also captures this mainstream market. Fully capturing the mainstream market is difficult, and so we believe that the threshold for 'successful' commercialization of an innovation will lie somewhere between these two extremes-a single sale on the one hand and saturating the mainstream of a market on the other. We therefore define the ability to commercialize innovations as a firm's capacity to bring a product into a market and reach the mainstream of the market beyond the initial adopters. A minimum threshold for 'success' in commercialization thus is embedded in our definition.

Converting technical innovations to products and services entails the development of production and marketing capabilities, and assets such as manufacturing facilities and service and distribution networks (Ahuja, 2000; Mitchell, 1989; Teece, 1986). Thus, there are three aspects to commercialization that require acknowledgment-(a) recognize a market for an innovation, (b) develop and manufacture it into a product or service, and (c) sell and distribute the product or service through distribution channels. While, the last two can be outsourced (i.e, licensed or franchised), the first one cannot. Thus, while the ability to commercialize innovations depends on the firm's ability to produce and sell the product or services either by itself or by contracting out, the ability to commercialize innovations is inextricably embedded in an organization's ability to recognize current or emerging market opportunities. 


\subsection{Networks and Resources}

The performance of firms in commercializing innovations can be explained by characteristics of the external network to which the firm belongs (Burkhardt, 1994; Burt, 1992; Dyer \& Singh, 1998; Podolny \& Stewart, 1995; Dourgerty \& Hardy, 1996; McGrath et al., 1996; Pennings \& Harianto, 1992; Teece, Pisano \& Shuen, 1997). Gupta, Tesluk and Taylor (2007) specified the importance of networks within a multilevel approach for studying innovation. They argued (citing Scott and Bruce, 1994) that an organization's climate of innovation emerges from the shared perception of members of the organization on the degree to which organizational policies, resources, procedures and practices support and encourage innovation. Nohria (1992) and Nohria \& Eccles (1992) have argued that the characteristics of an organization's network of social relations are relevant to a firm's ability to commercialize innovations.

Social, external and internal networks are considered as three different, albeit complementary, types of networks. They address different levels of analysis, use different theoretical constructs, and explain different outcomes of networks (Van Wijk, 2003). Social-networks thinking include organizations as social systems with a purpose, operating in a wider social structure. Organizations are differentiated by the network characteristics of the social relations they have with society and other organizations (Nohria, 1992). A social-network perspective provides an analytical tool to investigate structural, relational and positional embeddedness, tie strengths and trust (Nahapiet \& Ghoshal, 1998). External-network research tends to focus on networks as a governance mode intermediating markets and hierarchies (joint ventures and strategic alliances), plus highlighting the competitive dimension of networks and associated performance issues (Dyer \& Singh, 1998) along with the benefits of the networks such as interorganizational learning. Internal-network literature investigates intra-organizational structure and processes and management roles required for knowledge creation and sharing, maintaining flexibility, and enabling self-renewal (Volberda, 1998; Volberda \& Lewin, 2003).

While there is a clear distinction between the focus of these networks, their outcomes can be overlapping. For instance, Volberda \& Lewin (2003) argued that internal networks enable organizational self-renewal. Also, the distinction between social and external networks is not well defined. In fact Provan, Fish and Sydow (2007) mentioned that social networks often have been included within the construct of interorganizational or external networks, like the inclusion of social interaction as an attribute of interorganizational networks. Provan et al., (2007) mentioned that it is not entirely clear what organizational scholars are talking about when they use the term interorganizational networks. They noted that the term interorganizational network is used interchangeably with strategic alliances, coalitions, and cooperative arrangements, and has been tied to resource-dependence theory, transaction-cost economics, and interorganizational contracts. Despite these differences, Provan et al., (2007) argued that all definitions of interorganizational networks have common themes including social interaction, relationships, connectedness, collaboration, collective action, trust, and cooperation. Other common themes include business ecosystems (Moore, 1993) and clusters (Porter, 1998). Although great strides have been made in the study of interorganizational networks, a shared language with definitive meanings in the study of networks has not yet been developed (Provan et al., 2007). Consequently, the definition of what constitutes a network varies. On one hand it can be very generic, per Brass, Galaskiewicz, Geve, \& Tsai (2004) who explained "a network as a set of nodes and the set of ties representing some relationship, or lack of relationship, between the nodes." On the other hand, it can be to very specific, per Barringer and Harrison (1990) who provided an overview of different types of interorganizational networks and then went into considerable detail explaining how each is different within the rubric of networks and as being constellations of organizations that come together through the establishment of social contracts or agreements.

According to Gulati and Gargiulo (1999: 1439), "Organizations enter alliances with each other to access critical resources, but they rely on information from the network of prior alliances to determine with whom to cooperate. These new alliances modify the existing network, prompting an endogenous dynamic between organizational action and network structure that drives the emergence of interorganizational networks." While networks are formed to access and share resources (Dyer and Singh, 1998; Gnyawali, He and Madhvan, 2006; Gulati, 1998; Gulati and Kletter, 2005; Gulati, Nohria and Zaheer, 2000; Klein, Rai and Straub, 2007; Pfeffer and Salancik, 1978), the networks themselves become valuable resources (Barney, 1991; Porter, 1998; Mata, Fuerst, and Barney, 1995; Melville, Kraemer, and Gurbaxani, 2004). Thus, we treat networks and the resources they embody as one construct.

Synthesizing the above, we define networks as the collective of structures, collaboration, and norms within and between organizations. From an external-network standpoint this includes social networks, business clusters, partnerships, business ecosystems, and relationships with innovation engines, such as universities. From the standpoint of intraorganizational or internal networks, it includes the individuals in the organizations and the context of the organizational structure and organizational policies and procedures. These networks become a valuable resource, enabling organizational flexibility and leading to self renewal. 


\subsubsection{Networks and Commercialization of Innovations}

The structure, norms or collaboration of external networks often are explained by degree, centrality, multiplexity and broker relationships of networks (Borgatti and Everett, 2006; Freeman, 1977 \& 1979; Provan et al., 2007; Wasserman and Faust, 1994). Degree centrality is based on the number of direct links maintained by an organization with other organizations in the network (Borgatti \& Everett, 2006; Freeman, 1977 \& 1979). If the network is directed (meaning that ties have direction), then two separate measures of degree centrality are considered: in-degree and out-degree. In-degree is a count of the number of ties directed to the node, while out-degree is the number of ties that the node directs to others. Calculation of in-degree and out-degree centrality also is possible and is based on the extent to which assets such as resources, information, and clients are coming into an organization from others in the network versus those being sent out to other organizations. But, according to Provan et al., (2007), the key question will be: does an organization occupy a central or a more peripheral position in the network, based on the number of network ties it maintains with other organizations.

Burt (1992) argued that network linkages enable and constrain the flexibility, effectiveness, and innovativeness of organizational members. Newell \& Clark (1990) reported that British firms were less innovative than their U.S counterparts because they were less central in their interorganizational communication-networks. Further, Burns \& Wholey (1993) found that hospitals that were centrally located in an interorganizational network were more likely to be early adopters of innovations than those outside the network. Centrality determines the relative importance of an entity or a node in a network. While some organizations will struggle to get to the central position in any network, others will quickly link themselves to the central node (Dyer and Singh, 1998; Gnyawali, He and Madhvan, 2006; Gulati, 1998; Gulati and Kletter, 2005; Gulati, Nohria and Zaheer, 2000; Klein, Rai and Straub, 2007). Reasons for this difference in behavior could be many, for example, it could be expensive for the entities to maintain and control such networks, or it may be that the central node is a venture capitalist to which other nodes simply want to connect for financing, consulting, or access to business incubators. Thus, these "external networks" can involve business ecosystems (Moore, 1993), and that includes joint ventures and strategic alliances with suppliers and customers. Being in a central position or having a direct link to the central node within an external network, firms are better able to access resources, such as research, finance, production facilities and, distribution channels that are required for commercialization of innovations (Ahuja, 2000; Dyer \& Singh, 1998, Gnyawali, He, \& Madhvan, 2006; Klein, Rai \& Straub, 2007m Mitchel, 1989, Teece, 1986).

Closeness centrality addresses the question of whether or not an organization is in a structural position to spread resources such as information or knowledge that might reside in any organization in the network, even through indirect ties (Provan, et. al, 2007). Central organizations have short 'paths' (connections) to all other organizations in the network. Unlike degree centrality, indirect connections are viewed as valuable mechanisms for exchange of network-based resources in closeness centrality (Borgatti and Everett, 2006; Freeman, 1977 \& 1979). Betweenness measures the influence a node has over the spread of information through the network (Newman, 2005). If an organization serves as a gatekeeper within the network, then it must maintain intermediary links between organizations that are not directly connected with one another. Such organizations have benefits in accessing information about resources such as innovations and fundamental research, funding opportunities, manufacturing partners, and distribution channels. Thus, in terms of resource access, these gatekeepers are potentially at a greater advantage for commercializing innovations.

Multiplexity deals with the strength of the relationship an organization maintains with network partners, and is based on the number of types of links (e.g., research ties, joint programs, referrals, and shared personnel) that connects them (Provan et al., 2007). Multiplexity also is referred to as heterogeneity of networks (Newman, 2001). Multiplex ties are thought to be an indicator of the strength and durability of an organization's links because they enable the connection between an organization and its linkage partner to be sustained, even if one type of link dissolves (Provan et al., 2007). As already noted, external networks also can include ties with universities, along with various types of research laboratories and institutes that conduct basic research and are regarded as engines of innovation because they create new knowledge and literally are in the business of innovation (Agarwal, 2006; Chataway \& Wield, 2000; Colyvas et al., 2002; Numprasertchai \& Igel, 2005; Henderson, Jaffee \& Tratjenberg,1998). Though these innovation engines are not proximate in nature to commercial firms, they constitute a multiplex tie and can be treated under the same construct of external networks and resources.

Firms communicate with these innovation engines via formal and informal scientific meetings, licenses, joint ventures, research contracts, consulting, personal networks, research grants, recruitment of students, email, shared databases, workshops, communities of practice, and so on (e.g. Cohen et al., 1998; 2002; Powell, 1998; Oliver, 2004; Hoegl and Schulze, 2005; Rothaermel \& Thursby, 2005; Salman \& Saives, 2005). Such relationships help shorten the innovation cycle and promote faster commercialization. One example of such a tie would be the relationship that Nokia has with 
academic and research institutes in Finland (Birkinshaw \&Gibson, 2004). Through contracted, funded research, both the innovators and the commercializer benefit and the innovation/commercialization cycle appears to happen faster and more effectively (Birkinshaw \& Gibson, 2004).

Broker relationships explain the extent to which an organization span gaps, or structural holes, in a network (Burt, 1992; Provan et al., 2007). Such organizations are considered to be brokers, often occupying positions of considerable influence (Provan et al., 2007) and includes organizations such as banks or other financial agencies like venture capitalists. Broker relationship help organizations to get necessary funds for commercialization of innovations.

According to Kirzner (1997), discovery of entrepreneurial opportunities is somewhat probabilistic in nature, as opposed to the result of a systematic search effort. Thus, diversity increases the probability of a successful search occurring. Also, because entrepreneurs seem best able to "discover" opportunities for commercialization that directly relate to their previous knowledge in the three dimensions of knowledge of markets, knowledge of how to serve those markets, and knowledge of specific customers' problems (Shane, 2000), a robust network is required to support information gathering, resource sharing, and idea generation. This knowledge is not equally distributed across all entrepreneurs and, therefore, is necessarily a function of their relationships with innovators, and funders (Anderson, 2008). Thus, recognition of an opportunity to commercialize an innovation is more likely to happen at the confluence of these entities, facilitated by the entrepreneurial entity and its corresponding network. Opportunities are believed to be not a matter of 'particular individuals' (the neoclassical interpretation of the entrepreneur), but rather a combination of individuals (Vintergaard, 2005). Therefore, having the right parties in a network is critical.

The above discussion mainly has concentrated on the effect of interorganizational networks on commercialization of innovation. Past research also has contributed to our understanding of effects of internal networks on a firm's ability to commercialize innovations. The antecedents that have been studied have included structural factors in organizations (Nerkar, McGrath \& Macmillan, 1996; Scott \& Bruce, 1994) and leadership (Bantel \& Jackson, 1989; Ellis, 2003; Howell \& Higgins, 1990).

For instance, Ellis (2003) noted that in response to technological innovation and extremely volatile environmental conditions, competitive organizations increasingly are becoming horizontal in their reporting structure and have reduced the levels of management between the CEO and the lowest levels by $25 \%$. At the level of the individual, Nerkar et al., (1996) showed that three independent facets of job satisfaction - instrumental satisfaction with the way the task is progressing, social satisfaction with the way the team members interact with one another and the organization, and egocentric satisfaction with the individuals' perceived benefits to themselves - helps in commercialization of innovations. Scott and Bruce (1994) showed that leadership (leader-member exchange, leader-role expectation), individual problem-solving style (intuitive or systematic), and work-group relations influence the innovative climate of a firm, and Nevens et al., (1990) hypothesized that cross-functional skills are an antecedent to commercialization of technologies.

In differentiating between high- and low-performance firms, in terms of commercializing of innovations, Nevens et al., (1990) posited that, in high-performance companies, top management maintains a visible presence to reinforce commercialization. They found that even in extremely decentralized and divisionlized firms, like Hewlett Packard and $3 \mathrm{M}$, top management will involve themselves in details seen as crucial to the commercialization process. Further, the authors posited that in high-performance firms top-management teams act as tie breakers in disputes at the project level by giving precedence to commercialization of related activities over others, by ensuring a deadline is met, by clearing calendars of key employees of other work, speeding decision making, and making sure that the right people come together. Bantel and Jackson (1989), in their assessment of the effect top-management teams have on innovations in banking found that more innovative banks were managed by more educated teams that are diverse in their functional areas of expertise. These relationships remain significant when organizational size, team size, and location are controlled for. In assessing the effect of top management on technological innovations, Howell \& Higgins (1990) investigated the personality characteristics, leadership behaviors, and influence tactics of champions of technological innovations. They found that Champions exhibited higher risk-taking and innovativeness, initiated more influence attempts, and used a greater variety of influence tactics than non-champions.

Synthesizing the above, we posit that networks, be they within firms, between firms, or between firms and innovation engines not only will help in opportunity recognition but also in the remainder of the commercialization process. Networks thus help in moving innovations to markets, networks with financial agencies help raise funds for manufacturing, through networks firms can know if manufacturing can be outsourced to another entity or not, and they help in identifying the distribution channels for selling the products. This leads us to propose:

Proposition 1: Centrality, multiplexity, and broker relationships of external networks, and supportive structural and leadership factors of internal networks positively affect a firm's ability to commercialize innovations. 


\subsection{Ambidexterity: Balancing Exploration and Exploitation}

In order for an organization to succeed over the long term, it needs to master both adaptability and alignment, a dual mode that is termed as ambidexterity (Birkinshaw \& Gibson, 2004; Gibson \& Birkinshaw, 2004; Raisch \& Birkinshaw, 2008). As an example, Birkinshaw and Gibson (2004) noted that while Nokia launched a vast array of new mobile-technology product offerings, they also continued to make pricing and other product decisions in order to continue to be the dominant handset provider. Focusing too much on alignment makes an organization lose long-term vision, while emphasizing adaptability over alignment means building tomorrow's business at the cost of today's (Birkinshaw \& Gibson, 2004). Similarly, Duncan (1976) reasoned that in order to innovate successfully, organizations must balance two stages of innovation namely, initiation and implementation, and he referred to this balance as ambidexterity. During the initiation phase, an organization needs low formalization, with less centralization, whereas during implementation the organization needs more formalization, with lower complexity and higher centralization.

Similar to Birkinshaw and Gibson's (2004) idea of alignment and adaptability, and Duncan's (1976) idea of blending initiation with implementation, is March's (1991: p.71) concept of exploration and exploitation:

"Exploitation includes such things as refinement, choice, production, efficiency, selection, implementation, execution. Adaptive systems that engage in exploration to the exclusion of exploitation are likely to find that they suffer the costs of experimentation without gaining many of its benefits. They exhibit too many undeveloped new ideas and too little distinctive competence. Conversely, systems that engage in exploitation to the exclusion of exploration are likely to find themselves trapped in suboptimal stable equilibrium. As a result, maintaining an appropriate balance between exploration and exploitation is a primary factor in system survival and prosperity." Seen from the sense of Birkinshaw and Gibson (2004), March's conceptualization of exploration would be Nokia's experiment with newer technology and exploitation would be their continuing investment and commitment in their existing product lines.

Exploration, thus encompasses knowledge creation and analysis of emerging and future opportunities, while exploitation is defined as making use of existing knowledge to leverage current opportunities (March, 1991; Wielemaker, 2003; Sidhu, Commandeur, \& Volberda. 2007; Zack, 1999; Zack, 2003). Past research has positively linked a balance between exploration and exploitation with organizational self-renewal through constant innovations in volatile business environments (Lewin \& Volberda, 1999; Levinthal \& March, 1993; Levinthal, 1997; March, 1991; Nahapiet \& Ghosal, 1998; Volberda 1998; Volberda \& Lewin, 2003; Huber \& Glick, 1993; Hamel \& Getz, 2004). In addition, a number of studies collectively have posited that a balance between exploration and exploitation leads not only to organizational renewal but that this, in turn, helps firms to be more innovative and, as a result, such firms are more long-lived (Lewin \& Volberda, 1999; Levinthal \& March, 1993; Levinthal, 1997; Levinthal \& March, 1991; Volberda 1998; Volberda \& Lewin, 2003; Dess \& Beard, 1984; Hamel \& Prahalad, 2002; Hamel \& Getz, 2004). While some scholars defined the dual mode of operation of blending adaptability and alignment, exploration and exploitation, efficiency and flexibility as ambidexterity (Birkinshaw \& Gibson, 2004; Gibson \& Birkinshaw, 2004; Raisch \& Birkinshaw, 2008), others (e.g., Simsek, 2009) have mentioned that such a dual model itself leads to ambidexterity. Combining the work of March (1991), Birkinshaw \& Gibson (2004), Gibson \& Birkinshaw (2004), and Raisch \& Birkinshaw (2008), we define ambidexterity as the property of an organization to balance the two activities of exploration and exploitation.

From a thorough review of literature on ambidexterity Simsek, Heavey, Veiga and Souder (2009) and Simsek (2009) concluded that there are four ways to achieve a balance between exploration and exploitation, namely, harmonic, cyclical, partitional, and reciprocal. Harmonic balance is achieved through concurrently pursuing exploitation and exploration (Simsek et al., 2009), but attaining a balance means competition for scarce resources, which can lead to conflicts and inconsistencies. Organizational practice and routines that alleviate these problems are necessary for achieving a viable harmonic balance.

Cyclical ambidexterity is long periods of exploitation (or relative stability) interspersed by sporadic episodes of exploration (or change). Simsek et al., (2009), related it to Gersick's (1991) punctuated equilibrium. Antecedents to cyclical ambidexterity are found in human resource practices that emphasize innovation, teamwork, and flexibility (Simsek et al., 2009). Also, Simsek et al., (2009) traced partitional ambidexterity back to Duncan's (1976) work, where he emphasized the role of dual structure of initiation and implementation. Organizational theorist like Tushman and O'Reilly (1996), and O'Reilly and Tushman (2004) envisioned partitional ambidexterity as an interdependent, simultaneous phenomenon. From a structural perspective, partitional ambidexterity is achieved by creating separate units or divisions for exploitation and exploration (Duncan; 1976; Tushman and O'Reilly, 1996), with each unit embodying distinct strategic and operating logics, cultures, and incentive systems. As explained by O'Reilly \& Tushman (2004), the ability simultaneously to pursue both exploitation and exploration results from "hosting multiple contradictory structures, processes, and cultures within the same firm" (2004: 24). While tightly coupled and integrated at the business unit level, these logics must remain loosely coupled across business units (Benner and Tushman, 2003).

Reciprocal interdependence is where the outputs of exploitation from unit A become the inputs for exploration by unit $\mathrm{B}$ and the outputs of unit B cycle back to become the inputs of unit A (Simsek et al. 2009), this being the classic situation in strategic alliances. Lavie and Rosenkopf (2006: 814) observed that firms "appear to balance their tendencies to 
explore and exploit with respect to the nature of their alliances or choice of partners over time and across domains." Their findings highlight the significance of alliances and interorganizational networks as mechanisms for combining exploitation and exploration across time and units. In this vein, knowledge integration among alliance partners may be especially relevant to the pursuit of this form of ambidexterity (Simsek et al. 2009). We thus see that, irrespective of the type of balance, ambidexterity is enabled by networks (Birkinshaw and Gibson, 2004; Gibson and Birkinshaw, 2004; Raisch and Birkinshaw, 2008). But, collaboration within, between, and among organizations affects the ability to strike a balance between exploration and exploitation.

Simsek (2009) noted that centrality and multiplexity (cited as diversity) of networks affect ambidexterity. Centrally positioned organizations, because of their more numerous direct and indirect connections to others, have more relationships to draw upon in obtaining resources and so are less dependent on any single organization for exploration (Scott, 1991). In addition, the access facilitated by centrality means a higher likelihood of exposure to the various disparate social circles within the network and to more clusters, or pockets, of highly connected organizations (e.g. Powell et al., 1996; Simsek 2009). As a consequence, exploitation also is enabled because central organizations become better informed about what is going on in the network.

Network diversity improves the likelihood of achieving ambidexterity. Firstly, it provides the organization with the benefit of heterogeneity in its problem-solving arsenal (Simsek, 2009). An organization that has a homogenous network has little opportunity to consider multiple perspectives because most network members see the world similarly. By contrast, diverse ties imply organizations may differ in their modes of reasoning, problem formulation and solution. Exposure to these different approaches adds to the repertoire of ideas that the organization can bring to bear on exploitation and exploration, yielding deeper and more comprehensive analysis of design problems, and novel framing of opportunities (Baum et al., 2000; Beckman \& Haunschild, 2002; Simsek, 2009). Secondly, diverse network ties are valuable for ambidexterity because they can help the organization overcome the familiarity trap; that is, a tendency to favor the familiar over the unfamiliar (Ahuja \& Lampert, 2001; Simsek, 2009). Thirdly, diverse ties can promote ambidexterity by helping organizations overcome the convenience trap, a tendency to search for solutions that are in the neighborhood of existing solutions rather than search for completely new solutions (Ahuja \& Lampert, 2001; Simsek, 2009). Lastly, diverse ties also enable the organization to access a wider circle of information about potential markets, new business opportunities, innovations, sources of capital, and potential customers. Thus, an organization with heterogeneous partners is likely not only to have access to more complementary resources but also to know more about how to productively put these resources into use (Burt, 1992; Simsek, 2009). For example, through its strong relation with universities in Finland, Nokia is able to experiment with a vast array of new mobile-technology inventions (such as the Nokia Symbian operating system) relatively inexpensively, while continuing to invest in being the dominant handset franchise, thereby enabling their ambidexterity (Birkinshaw and Gibson, 2004).

The ability of ambidextrous firms to come up with radical new products without hampering activities in existing markets, make them long-lived (Tushman \& O'Reilly, 1996, 2002; O'Reilly \& Tushman, 2004). The works of Collin and Poras (1999), Huygens et al.(2001), Porter (1998), and Van Wijk (2003) suggest that long lived-firms have structural and cultural similarities, and from the standpoint of intraorganizational networks, Tushman and O'Reilly (1996) identified a decentralized structure, a common culture and vision, and supportive leaders and flexible managers as key sources of ambidexterity. Thus, factors within firms that affect ambidexterity include decentralization, a tolerant management style, and sensitivity towards the emerging trends in the environment. Similarly, co-evolutionary theory (Van den Bosch et al. 1999; Flieret al., 2003; Volberda \& Lewin, 2003) speaks to the interdependence of organizations and their environments. Combining work on corporate longevity and co-evolutionary theory, Volberda \& Lewin (2003) proposed three key principles of self renewal within organizations: (a) self renewing organizations focus on managing requisite variety by regulating internal rates of change equal to or exceeding external rates of environmental change triggered by customer orientation, technology innovation, industry competition, and product obsolescence; (b) self-renewing organizations optimize self-reorganization; and (c) self-renewing organizations synchronize concurrent exploitation and exploration. Therefore, the management of internal and external networks can enable a firm continuously to renew and fit within a changing business environment.

Synthesizing the above, we propose:

Proposition 2A: An organization's ability to create and manage inter- and intra-organizational networks positively affects its ability to balance exploration and exploitation.

Technologically oriented organizations that engage in successive or cyclic rounds of exploitation and exploration are best equipped to pursue product innovations (Tushman and O'Reilly, 1996; Simsek et al, 2009; Simsek, 2009). By engaging in intensive periods of exploration, firms discover new technologies that not only spur the proliferation of new 
products, but also can become established as the dominant design in the industry (Henderson \& Clark, 1990). Then, by subsequently shifting to exploitation, they can improve the performance of product innovations through process innovation (Simsek et al, 2009). Partitional-ambidextrous firms have been observed to be successful in launching breakthrough products and services and in ensuring the continued high performance of existing products (O' Reilly \& Tushman, 2004).

Tushman and O'Reilly (1996) argued that large corporations, such as Johnson \& Johnson, and Asea Brown Boveri (ABB), have been able to compete in mature market segments through incremental innovation, and in emerging market segments through discontinuous innovation. They reconcile conflicting demands from their task environment and synchronize and balance concurrent exploration of new opportunities and exploitation of existing ones (Duncan, 1976; Gibson \& Birkinshaw, 2004; Birkinshaw and Gibson, 2004; O'Reilly \& Tushman, 2004; Tushuman \& O'Reilly, 1996). In this way, ambidextrous organizations can renew themselves through the creation of breakthrough products, services and processes without destroying or hampering traditional businesses (Gibson \& Birkinshaw, 2004; Volberda \& Lewin, 2003; Tushman \& O’Reilly, 1996).

We already have mentioned that ambidextrous firms are better able to attain organizational longevity, and that such long-lived organizations compete in mature market segments through incremental innovations (Abernathy \& Utterback, 1978; Christensen, 1992a and 1992b) and in emerging market segments through radical innovations (Burgelman, Christensen, \& Wheelwright, 2006; Abernathy \& Utterback, 1978; Burgelman \& Grove, 1996; Burgelman, 2002; Galunic \& Eisenhardt, 1996; Christensen, 1992a; Henderson \& Clark, 1990 ). For instance, the ability of Hewlett Packard to balance its mainstream computing and printing market with emerging IT service markets led to leading products in computers, printers and IT services, like HP open view. Thus, being ambidextrous leads a firm to combine current opportunities with future vision, which, per our definition of ability to commercialize innovations, includes being able to recognize current and emerging markets. Further, we have argued that the ability to balance exploration and exploitation leads to an organization's being cognizant of existing and emerging markets, and capitalize on both types of market opportunities. Therefore:

Proposition 2B: The better the balance between a firm's exploitation and exploration, the more successful it will be at commercialization of innovations.

\subsection{Absorptive Capacity}

According to Cohen and Levinthal (1990) and Jansen et al. (2005), absorptive capacity is the limit to the quantity and rate at which a firm can absorb scientific or technological information. Conceptually, absorptive capacity is similar to information-processing capacity but at the firm level rather than at the individual level. Absorptive capacity underlies a firm's knowledge capabilities by which the firm acquires, assimilates, transforms, and exploits knowledge resources to produce dynamic capabilities such as innovativeness (Zahra and George 2002). Networks affect absorptive capacity. Not only are they important for increasing a firm's knowledge base and for creating new knowledge, which can be observed in the form of new patents (which are embodiments of knowledge), new categories of products and services (which come from understanding the competition and market needs) and, in extreme cases, the creation of new industries (Jansen et al., 2005), they also play an important role in building a firm's absorptive capacity by providing skills and processing abilities that can support the acquisition, assimilation, transformation, and exploitation of knowledge for innovation (Alavi \& Leidner 2001; Holsapple \& Joshi, 2000; Holsapple and Joshi, 2002; Dehning et al. 2003; Jansen et al., 2005; Lane \& Lubatkin, 1998; Zahra \& George, 2002). The primary antecedents to absorptive capacity, according to Cohen \& Levinthal (1990), are the structure of communication between the organization and entities in its external environment (termed outward absorptive capacity), the structure of communication between subunits in the organization (termed cross-functional absorptive capacity), and the structure of communication within subunits in the organization (termed inward absorptive capacity). The latter is self evident insofar as good communication within units will permit more and quicker absorption of knowledge than will poor communication, but outward and functional absorptive capacity need some illustration and explanation.

Some examples of outward absorptive capacity are the strategic partnership between Intel and Microsoft (Grove, 1996), the business ecosystem that Walmart created with its suppliers (Moore, 1993; Burgelman et al., 2006), and the relationship that Nokia has with academic and research institutions. In each case the experiences or knowledge of one firm or entity increases the limit of absorption of the other entity over the network. A classic example of cross functional absorptive capacity is the tight linkages between design and manufacturing subunits that enabled Japanese firms to move products rapidly from design through production, marketing, sales, and into the market (Cohen and Levinthal, 1990). The concept was explained in more detail by Clark \& Fujimoto (1987) who argued that overlapping product-development cycles facilitated collaboration and coordination across subunits within a firm. Cross-functional 
interfaces, organizational networks, and socialization were shown to be important for the development of absorptive capacity (Jansen et al. ,2005) and, an organic structure has been deemed as being desirable for promoting absorptive capacity because it better enables people to solve unstructured problems quickly and well (Cohen \& Levinthal, 1990; Chen, 2004; Jansen et al., 2005). Thus, structure and collaboration within intraorganizational networks, can affect its absorptive capacity.

Further, the relationships between firms, and between firms and innovation engines affect a firm's absorptive capacity (Cohen and Levinthal, 1990; Cohen et al. 1998, 2002). Cohen et al. (1998; 2002) noted that publications, public meetings and conferences, informal and personal exchanges of information, and consulting contracts appear to be the four primary channels for knowledge exchange between firms and innovation engines. The relative importance of the channels also may vary across industries. Cohen and Levinthal (1990), and Cohen et al., (2002) found that some channels are more important than others for exchange of knowledge. Similarly, Powell (1998), Oliver (2004), Salman and Saives (2005), and Lin et al.,(2006) also noted idiosyncrasies in channel use. From these works, it appears that networks between academia and industry can benefit participating firms in that there is a useful flow of knowledge either in the sharing of research findings, or through the guidance of the scientist (e.g., if the scientist were to serve as an advisor or board member for the participating firm) or in some case through transfer of intellectual property. Thus, as Cohen and Levinthal (1990) concluded, these types of networks between firms and innovation engines expand an organization's absorptive capacity. From the discussions above we posit that firms with networks with other firms and with innovations engines will have greater absorptive capacity than those without. We therefore posit:

Proposition 3A: Absorptive capacity is positively related to a firm's internal and external networks - as the number of networks, and the quality of linkages (number, type, tightness) increase, so too does absorptive capacity.

Cohen \& Levinthal (1990) argued that absorptive capacity allows firms to predict more accurately the commercial potential of technological advances. In other words, a higher absorptive capacity can promote innovation within a firm as well as its ability to comprehend the commercial potential of innovations. Both inward and outward absorptive capacity can increase the ability to commercialize innovations. For instance, as Clark and Fujimoto (1987) found, the overlapping interfaces between design, manufacturing, sales and marketing in Japanese firms led to increased absorptive capacity leading to movement of the product from design, to market. Similarly, outward absorptive capacity, derived from networks between firms and innovation engines, increases the ability to commercialize innovations, as innovators can view their innovations as finished products and firms can sense the business value of fundamental research. Nokia has done exactly that with its networks with academia (Birkinshaw and Gibson, 2004).

Again, in our definition of ability to commercialize innovations, we included an organization's ability to recognize current and emerging markets as a fundamental component. From the above, it is apparent that absorptive capacity underpins that ability. Therefore:

Proposition 3B: Higher absorptive capacity increases a firm's ability to commercialize innovations.

\subsection{Moderating Factors}

\subsubsection{Intensity of Environmental Turbulence}

Goldsmith and Mechling (2008) identified four stages of environmental change: stable, evolutionary, revolutionary and turbulent. In a stable environment the need to develop new innovations is low, while during turbulent times, the need to innovate and commercialize is extremely high (Goldsmith and Mechling, 2008), and its resource allocation and mobilization also will be different in stable and turbulent environments (Eisenhardt \& Martin, 2000; Teece et al., 1997, Volberda, 1996; Wade \& Hulland, 2004).

According to Ghemawat and Costa (1993), firms faced with more stable environments tend to emphasize static efficiency at the expense of dynamic efficiency, and the process is reversed when firms find themselves in unstable environments. In other words, a firm tends to be inward looking during stable times and outward looking during disruptions. Cohen \& Levinthal (1990) argued that in an uncertain environment, absorptive capacity permits the firm to predict more accurately the mature and commercial potential of technological advances. In highly dynamic environments, there is rapid and discontinuous change in demand, competitors, technology, or regulations. As a result, information often is inaccurate, unavailable, or obsolete (Eisenhardt and Bourgeois, 1988; Simsek, 2009). Dynamic environments thus demand that the organization develop adaptive responses quickly and expand the scope of information acquisition and gathering (Sidhu et al., 2004; Simsek, 2009). In so doing, dynamism imposes a challenge to the organization by demanding flexibility and agile actions ranging from information scanning, selection, and processing to interpretation (Miller and Friesen, 1983; Simsek, 2009). 
We also must realize that for centrally positioned organizations, a turbulent environment puts strains on an organization's information-processing capability (Simsek, 2009). Absorptive capacity is information processing capacity at the firm level (Cohen and Levinthal, 1990). Such information overload may impede organizations from realizing potential values of certain innovations, and cripple their ability correctly to assess the diverse information and knowledge benefits that come from networks (Simsek, 2009). Thus, while environmental turbulence gives an impetus to increase absorptive capacity, it will, in reality, inhibit it. Therefore:

\section{Proposition 4A. Environmental turbulence negatively moderates the relationship between} networks and absorptive capacity.

During stable times, a firm exploits existing markets and the impetus for exploring new possibilities is low, while in times of environmental disruptions the need to explore emerging markets without hurting existing markets is higher (Leornard-Barton, 1992; Levinthal \& March, 1993; Melville et al. 2004). As noted earlier, successful long-lived firms tend to be ambidextrous, but their need to be ambidextrous is higher in the face of environmental turbulence. Simsek (2009), however, posited that during turbulent or dynamic environmental conditions, over-reliance on inter-organizational networks may prevent centrally positioned organizations from responding in a timely manner while, at the same time, coordination, information processing, and collaboration become more expensive and difficult to manage in a dynamic environment because of rapidly unfolding conditions and contingencies. In addition, Simsek (2009) argued that the positive effects of network diversity or multiplexity on ambidexterity may be dampened by environmental turbulence. We argued earlier that for organizations to be able to improve their ambidexterity from diverse network ties, they first must sufficiently access, process, and utilize the diverse information and knowledge benefits that these ties provide. But, dynamism will force the organization to develop solutions by taking actions quickly without utilizing the integrative benefits of the network ties. In addition to reducing the benefits, environmental dynamism also can increase costs associated with diverse array of ties because of changes in network memberships and relationships. The cost with some structural elements of interorganizational networks, such as centrality and multiplicity, may outweigh the benefits of ambidexterity. Since we have already stated that structural elements of networks affect ambidexterity, we propose that:

Proposition 4B. Environmental turbulence negatively moderates the relationship between networks and ambidexterity.

\subsubsection{Environmental Munificence}

An environment is said to be munificent to the extent that it supports a firm's continued and sustained growth (Dess \& Beard, 1984). Environments that are mature and shrinking are characterized by low munificence, while an industry that is growing is said to have relatively high munificence (Keats and Hitt, 1988).

A mature environment is characterized by regularity and predictability of market changes (Duncan, 1972; Dess \& Beard, 1984; Keats and Hitt, 1988), where more information is available concerning partners, competitors, and their potential actions, and where firms are better able to assess and predict effects of actions (Milliken, 1987). Therefore, firms in mature environments tend to focus on increasing efficiency rather than creating new knowledge and launching new products, which are both time-consuming and resource-consuming. Firms that explore newer opportunities in a mature environment may not do any better than those that do not. Thus, the need to be ambidextrous is lower in a mature environment than in growth environment. For low environmental-munificence, firms will tend toward more exploitation rather than exploration, whereas firms faced with high environmental-munificence will have a need to take advantage of the opportunities around them because, if they do not, their competitors will. Firms in a munificent environment therefore will tend to have a better balance of exploration and exploitation. We propose:

\section{Proposition 5. Environmental munificence positively moderates the relationship between networks} and ambidexterity.

\subsubsection{Environmental Complexity}

Dess and Beard (1984), defined complexity as the heterogeneity and concentration of environmental elements. A highly complex environment is characterized by the level of heterogeneity of firms within the industry, a high number of suppliers and customers, and a wide range of products being offered (Wade \& Hulland, 2004). Simsek (2009) noted that an organization's environment is more complex to the extent that the organization needs to consider heterogeneous actors and a range of activities, linkages, and interactions outside its boundaries in strategic decision-making.

Environmental complexity exerts its primary influence on organizational structure (Keats and Hitt, 1988). MacCrimmon and Taylor (1976) and Bobbitt and Ford (1980) suggested that organizational decision-makers deal with environmental complexity by structural divisionalization. Divisionalization allows development of specialized knowledge to deal with 
specific environmental elements and creates decentralized decision-making authority to take needed actions (Keats and Hitt, 1988), and such development of specialized knowledge, through creation and assimilation, were, according to Lane and Lubatkin (1998), indicators of absorptive capacity. Thus, we can deduce that environmental complexity provides the impetus to align resources and networks to develop absorptive capacity. This leads us to posit:

\section{Proposition 6A: Environmental complexity positively moderates the relationship between networks and absorptive capacity.}

Complex environments do not diminish an organization's ability to take action, but it makes it difficult to identify what is most appropriate (Boisot and Child, 1999). Considering the demands of a complex environment in understanding the critical drivers of success, network centrality and diversity (multiplexity or heterogeneity) will lead to greater ambidexterity in a complex environment than in a simple environment (Boisot and Child, 1999; Simsek, 2009). Particularly, while a complex environment demands greater levels of ambidexterity, centrality and diversity enhance the organization's ability to develop ambidextrous responses to maintain an appropriate level of fit with the environment as well as strategic flexibility such that complexity does not mitigate its ability to develop appropriate actions (Boisot and Child, 1999; Simsek, 2009). In other words complex environments demand a wider array of knowledge and perspectives for developing and evaluating solutions to complex and multifaceted problems. Thus, complexity is likely to increase the beneficial influences of network centrality and diversity on ambidexterity. Indeed, research by Powell et al. (1996) shows that in industries that are complex and expanding, with sources of expertise that are widely dispersed, network ties tend to become salient predictors of the organization's innovation performance. Similarly, through central and diverse network connections, the organization is better positioned for developing the increased number of responses that are needed to attain ambidexterity in a complex environment (Simsek, 2009). Therefore:

\section{Proposition 6B: Environmental complexity positively moderates the relationship between networks and ambidexterity.}

While turbulence and complexity both moderate the relationship between networks and ambidexterity, the direction of the relationship is different. The reason, as posited by Simsek (2009), is that whereas dynamism results in an inability to predict and foresee, complexity is, instead, associated with difficulty in monitoring.

\section{Conclusions and Implications}

We began by asking a very practical question as to why some organizations are better at commercializing innovations than are others. Our investigation of the literature has helped identify the antecedents, mediators, and moderators to the commercialization of innovation and, from this, we have created an integrative model. In addition to elucidating commercialization of innovations, this work also contributes to our thinking on the various facets of networks, absorptive capacity, and ambidexterity.

While commercialization of innovations essentially is bringing innovations to market, the task differs greatly when a firm tries to compete in an existing market versus create a new one, or when the innovation is incremental versus radical. This led us to underscore the importance of ambidexterity. Realizing the market potential of an innovation is fundamental to commercialization of innovations, and such, it is contingent a firm's absorptive capacity. Further, the antecedents to both ambidexterity and absorptive capacity can be found in networks within a firm, between firms, and between firms and innovation engines. These networks directly affect a firm's ability to commercialize innovations, not only by helping in recognizing market opportunities for innovations, but also by helping in accessing resources required for manufacturing and distribution. In addition, the relationships that networks have with absorptive capacity and ambidexterity are moderated by environmental turbulence, munificence and complexity.

Our model suggests that for a firm to remain competitive it must do a number of things well. First, creation of an environment that fosters knowledge sharing and diffusion of knowledge through deployment of a number of internal mechanisms is crucial. Second, alliances with external partners are needed to access and direct resources towards commercialization of innovations. Both these activities lead to an ability to increase absorptive capacity, and the ability to explore new areas and exploit current opportunities. Third, alliances can include innovation engines such universities and research organizations, and leveraging these relationships can increase absorptive capacity. Lastly, an understanding of nature of the environment within which the firm operates and how that affect the ability to commercialize innovations also is crucial for success.

Before these or any other lessons can be acted up on with confidence, much research remains to be done. Each of the propositions offered in this paper opens doors for empirical research and further theoretical understanding. Surveys or secondary data sets can be used to conduct positivist research in order to test the propositions, while detailed case studies of firms in specific industries under given circumstances may aid in attaining an interpretivist understanding of commercialization of innovation that is deeper, richer, and more detailed. 
All work has limitations. In this work we treated ambidexterity and absorptive capacity as two distinctive constructs with no overlap. There could be a cause and effect relationships between the two constructs, but for theoretical simplicity we are treated them as distinct. Also, this paper does not distinguish between the consequences of inter-organizational networks, intra-organizational networks, or networks between firms and innovation engines. Again, to keep the model manageable, we have treated networks as one entity. Future research should be geared towards - (a) showing how each type of network contributes towards commercialization of innovations, ambidexterity and absorptive capacity, (b) how each type of network relates to the others, and (c) how absorptive capacity and ambidexterity relate to each other.

We have posed a timely research question, and provided a theoretical model to address the question. While the thinking in this work is of relevance to practice, our intent has been to generate a model that acts as a catalyst for scholars to extend existing research on the commercialization process and, thus, create an even deeper understanding of this crucial business activity.

\section{References}

Abernathy, W. J., \& Utterback, J. M. (1978). Patterns of industrial innovation. Technology Review, 80(7), 40-47.

Abrahamson, E., \& Rosenkopf, L. (1993). Institutional and competitive bandwagons: Using mathematical modeling as a tool to explore innovation diffusion. Academy of Management Review, 18(3), 487-517.

Agarwal, A. (2006). Engaging the inventor: Exploring licensing strategies for university inventions and the role of latent knowledge. Strategic Management Journal 27, 63-79. doi:10.1002/smj.508, http://dx.doi.org/10.1002/smj.508

Ahuja, G. (2000). The duality of collaboration: Inducements and opportunities in the formation of interfirm linkages. Strategic Management Journal, 21(3), 317-343. doi:10.1002/(SICI)1097-0266(200003)21:3<317::AID-SMJ90>3.0.CO;2-B, http://dx.doi.org/10.1002/(SICI)1097-0266(200003)21:3\%3C317::AID-SMJ90\%3E3.0.CO;2-B

Ahuja, G., \& Lampert, C. M. (2001). Entrepreneurship in the large corporation: A longitudinal study of how established firms create breakthrough inventions. Strategic Management Journal, 22(6/7), 521-543. doi:10.1002/smj.176, http://dx.doi.org/10.1002/smj.176

Alavi, M., \& Leidner, D. E. (2001). Knowledge management and knowledge management systems: Conceptual foundations and research issues. MIS Quarterly, 25(1), 107-136. doi:10.2307/3250961, http://dx.doi.org/10.2307/3250961

Anderson, M. H. (2008). Social networks and the cognitive motivation to realize network opportunities: A study of managers' information gathering behaviors. Journal of Organizational Behavior, 29(1), 51-78. doi:10.1002/job.459, http://dx.doi.org/10.1002/job.459

Andrew, J. P., \& Sirkin, H. L. (2003). Innovating for cash. Harvard Business Review, 81(9), 76-83.

Ariño, A., \& Reuer, J. J. (2006). Strategic alliances: Governance and contracts. New York: Palgrave Macmillan.

Bantel, K. A., \& Jackson, S. E. (1989). Top management and innovations in banking: Does the composition of the top team make a difference? Strategic Management Journal, 10(Summer), 107-124. doi:10.1002/smj.4250100709, http://dx.doi.org/10.1002/smj.4250100709

Barney, J. B. (1986). Organizational culture: Can it be a source of sustained competitive advantage? Academy of Management Review, 11(3), 656 - 665.

Barney, J. B. (1991). Firm resources and sustained competitive advantage. Journal of Management, 17(1), 99-120. doi:10.1177/014920639101700108, http://dx.doi.org/10.1177/014920639101700108

Barringer, B., \& Harrison, J. (2000). Walking a tightrope: Creating value through interorganizational relationships. Journal of Management, 26(3), 367-403. doi:10.1177/014920630002600302, http://dx.doi.org/10.1177/014920630002600302

Baum, J. A. C., Calabrese, T., \& Silverman, B., S. (2000). Don't go it alone: Alliance network composition and startups' performance in Canadian biotechnology. Strategic Management Journal, 21(3), 267-294. doi:10.1002/(SICI)1097-0266(200003)21:3<267::AID-SMJ89>3.0.CO;2-8, http://dx.doi.org/10.1002/(SICI)1097-0266(200003)21:3\%3C267::AID-SMJ89\%3E3.0.CO;2-8 
Beckman, C. M., \& Haunschild, P. R. (2002). Network learning: The effects of partners' heterogeneity of experience on corporate acquisitions. Administrative Science Quarterly, 47(1), 92-124. doi:10.2307/3094892, http://dx.doi.org/10.2307/3094892

Benner, M. J., \& Tushman, M. L. (2003). Exploitation, exploration, and process management: The productivity dilemma revisited. Academy of Management Review, 28(2), 238-256.

Birkinshaw, J., \& Gibson, C. (2004). Building ambidexterity into an organization. Sloan Management Review, 45(4), 46-55

Bobbitt, H. R., Jr, \& Ford, J. (1980). Decision maker choice as a determinant of organizational structure. Academy of Management Review, 5, 13-23.

Borgatti, S. P. (2005). Centrality and network flow. Social Networks, 27(1), 55-71. doi:10.1016/j.socnet.2004.11.008, http://dx.doi.org/10.1016/j.socnet.2004.11.008

Borgatti, S. P., \& Everett, M. G. (2006). A graph-theoretic perspective on centrality. Social Networks, 28(4), 466-484. doi:10.1016/j.socnet.2005.11.005, http://dx.doi.org/10.1016/j.socnet.2005.11.005

Brass, D. J., Galaskiewicz, J., \& Greve, H. R. (2004). Taking stock of networks and organizations: A multilevel perspective. Academy of Management Journal, 47(6), 795-817. doi:10.2307/20159624, http://dx.doi.org/10.2307/20159624

Brynjolfsson, E., \& Mendelson, H. (1993). Information systems and the organization of modern enterprise. Journal of Organizational Computing, 3, 245-255. doi:10.1080/10919399309540203, http://dx.doi.org/10.1080/10919399309540203

Burgelman, R., A., \& Grove, A. S. (1996). Strategic dissonance. California Management Review, 38(2), 8-28.

Burgelman, R. A. (2002). Strategy as vector and the inertia of coevolutionary lock-in. Administrative Science Quarterly, 47(2), 325-357. doi:10.2307/3094808, http://dx.doi.org/10.2307/3094808

Burgelman, R. A., Christensen, C. M., \& Wheelright., S. C. (2006). Strategic management of technology and innovation. New York: McGraw Hill Irwin.

Burkhardt, M. E. (1994). Social interaction effects following a technological change: A longitudinal investigation. Academy of Management Journal, 37(4), 869-898. doi:10.2307/256603, http://dx.doi.org/10.2307/256603

Burns, L. R., \& Wholey, D. R. (1993). Adoption and abandonment of matrix management programs: Effects of organizational characteristics and interorganizational networks. Academy of Management Journal, 36(1), 106-138. doi:10.2307/256514, http://dx.doi.org/10.2307/256514

Burt, R. S. ( 1992). Structural holes: The social structure of competition. Cambridge, MA: Harvard University Press.

Chataway, J., \& Wield, J. (2000). Industrialization, innovation and development: What does knowledge management change? Journal of International Development, 12(6), 803-824.

doi:10.1002/1099-1328(200008)12:6<803::AID-JID714>3.0.CO;2-H,

http://dx.doi.org/10.1002/1099-1328(200008)12:6\%3C803::AID-JID714\%3E3.0.CO;2-H

Chen, C. J. (2004). The effects of knowledge attribute, alliance characteristics, and absorptive capacity on knowledge transfer performance. $R \& D$ Management, 34(3), 311-321. doi:10.1111/j.1467-9310.2004.00341.x, http://dx.doi.org/10.1111/j.1467-9310.2004.00341.x

Child, J. (1972). Organizational structure, environment and performance: The role of strategic choice. Sociology, 6(1), 1-22. doi:10.1177/003803857200600101, http://dx.doi.org/10.1177/003803857200600101

Christensen, C. M. (1992a). Exploring the limits of the technology s-curve. Part I: Component technologies. Production and Operations Management, 1(4), 334-357. doi:10.1111/j.1937-5956.1992.tb00001.x, http://dx.doi.org/10.1111/j.1937-5956.1992.tb00001.x

Christensen, C. M. (1992b). Exploring the limits of the technology s-curve. Part II: Architectural technologies. Production and Operations Management, 1(4), 358-366. doi:10.1111/j.1937-5956.1992.tb00002.x, http://dx.doi.org/10.1111/j.1937-5956.1992.tb00002.x

Clark, K. B., \& Fujimoto, T. (1987). Overlapping problem-solving in product development. Cambridge, MA: Harvard University Press. 
Cohen, S. S., \& Fields, G. (1999). Social capital and capital gains in Silicon Valley. California Management Review, 41(2), 108.

Cohen, W. M., Florida, R., Randazzes, L., \& Walsh, J. (1998). Industry and the academy: Uneasy partners in the cause of technological advance. In R. Noll (Ed.), Challenges to Research Universities (pp. 171-200). Washington, DC: The Brookings Institution.

Cohen, W. M., \& Levinthal, D. (1990). Absorptive capacity: A new perspective on learning and innovation. Administrative Science Quarterly 35(1), 128-152. doi:10.2307/2393553, http://dx.doi.org/10.2307/2393553

Cohen, W. M., Nelson, R. R., \& Walsh, J. P. (2002). Links and Impacts: The Influence of Public Research on Industrial R\&D. Management Science, 48(1), 1-23. doi:10.1287/mnsc.48.1.1.14273, http://dx.doi.org/10.1287/mnsc.48.1.1.14273

Collin, J. C., \& Porras, J. I. (1997). Built to last: Successful habits of visionary companies. New York: Harper Business.

Colyvas, J., Crow, M., Gelijns, A., Mazzoleni, R., Nelson, R. R., Rosenberg, N., et al. (2002). How do university inventions get into practice? Management Science, 48(1), 61-72. doi:10.1287/mnsc.48.1.61.14272, http://dx.doi.org/10.1287/mnsc.48.1.61.14272

Damanpour, F. (1991). Organizational innovation: A meta-analysis of effects of determinants and moderators. Academy of Management Journal, 34, 555-590 doi:10.2307/256406, http://dx.doi.org/10.2307/256406

Dehning, B., Richardson, V. J., \& Zmud., R. W. (2003). The value relevance of transformational information technology investments. MIS Quarterly 27(4), 637-656.

Dess, G. G., \& Beard, D. W. (1984). Dimensions of organizational task environments. Administrative Science Quarterly, 29(1), 52-73. doi:10.2307/2393080, http://dx.doi.org/10.2307/2393080

Dougerty, D., \& Hardy, C. (1996). Sustained product innovation in large mature organizations: Overcoming innovation-to-organization problems. Academy of Management Journal, 39(5), 1120-1153 doi:10.2307/256994, http://dx.doi.org/10.2307/256994

Drucker, P. (1985). Innovation and entrepreneurship: Practice and principles. New York: Harper and Row.

Duncan, R. B. (1972). Characteristics of organizational environments and perceived environmental uncertainty. Administrative Science Quarterly, 17(3), 313-327. doi:10.2307/2392145, http://dx.doi.org/10.2307/2392145

Duncan, R. B. (1976). The ambidextrous organization: Designing dual structures for innovation. The Management of Organization: Strategy and Implementation, 1, 167-188.

Dyer, J. H., \& Singh, H. (1998). The relational view: Cooperative strategy and sources of interorganizational competitive advantage. Academy of Management Review, 23(4), 660-679.

Eisenhardt, K. M., \& Bourgeois, i., L. J. (1988). Politics of strategic decision kaking in high-velocity environments: Toward a midrange theory. The Academy of Management Journal, 31(4), 737-770. doi:10.2307/256337, http://dx.doi.org/10.2307/256337

Eisenhardt, K. M., \& Martin, J. A. (2000). Dynamic capabilities: What are they? Strategic Management Journal, 21(10/11), 1105-1121. doi:10.1002/1097-0266(200010/11)21:10/11<1105::AID-SMJ133>3.0.CO;2-E, http://dx.doi.org/10.1002/1097-0266(200010/11)21:10/11\%3C1105::AID-SMJ133\%3E3.0.CO;2-E

Ellis, C. (2003). The Flattening corporation. Sloan Management Review, 44(4), 5.

Flier, B., Van Den Bosch, F. A., \& Volberda, H. W. (2003). Co-evolution in strategic renewal behaviour of British, Dutch and French financial incumbents: Interaction of environmental selection, institutional effects and managerial intentionality. Journal of Management Studies, 40(8), 2163-2187. doi:10.1046/j.1467-6486.2003.00416.x, http://dx.doi.org/10.1046/j.1467-6486.2003.00416.x

Freeman, L. C. (1977). A set of measures of centrality based on betweenness. Sociometry, 40(1), 35-41. doi:10.2307/3033543, http://dx.doi.org/10.2307/3033543

Freeman, L. C. (1979). Centrality in social networks: conceptual clarification. Social Networks, 1(3), 215-239. doi:10.1016/0378-8733(78)90021-7, http://dx.doi.org/10.1016/0378-8733(78)90021-7

Freeman, L. C. (1980). The gatekeeper, pair-dependency, and structural centrality. Quality and Quantity 14(4), 585-592. doi:10.1007/BF00184720, http://dx.doi.org/10.1007/BF00184720 
Galunic, D. C., \& Eisenhardt, K. M. (1996). The evolution of intracorporate domains: Divisional charter losses in high-technology, multidivisional corporations. Organization Science, 7(3), 255-282. doi:10.1287/orsc.7.3.255, http://dx.doi.org/10.1287/orsc.7.3.255

Gersick, C. J. G. (1991). Revolutionary change theories: A multilevel exploration of the punctuated equilibrium paradigm. Academy of Management Review, 16(1), 10-36.

Ghemawat, P., \& Costa, J. E. R. I. (1993). The organizational tension between static and dynamic efficiency. Strategic Management Journal, 14, 59-73. doi:10.1002/smj.4250141007, http://dx.doi.org/10.1002/smj.4250141007

Gibson, C. B., \& Birkinshaw, J. (2004). The antecedents, consequences, and mediating: Role of organizational ambidexterity. Academy of Management Journal, 47(2), 209-226. doi:10.2307/20159573, http://dx.doi.org/10.2307/20159573

Gnyawali, D. R., He, J., \& Madhvan, R. (2006). Impact of co-opetition on firm competitive behavior: An empirical Analysis. Journal of Management, 32(4), 507-530. doi:10.1177/0149206305284550, http://dx.doi.org/10.1177/0149206305284550

Goldsmith, S., \& Mechling, J. (2008). Turbulence, innovation and leadership: Adapting to change in the $21^{\text {st }}$ century. John F. Kennedy School of Government, Harvard University.

Granovetter, M. (1976). The strength of weak ties. The American Journal of Sociology, 78(6), 1360-1380. doi:10.1086/225469, http://dx.doi.org/10.1086/225469

Granovetter, M. (2003). The strength of weak ties. In A. P. R. Cross \& L. Sasson (Eds.), Networks in the knowledge economy (pp. 109-129). New York: Oxford University Press.

Grove, A. S. (1996). Only the paranoid survives: Exploit the crisis point that challenge every company and career. New York: Doubleday Dell Publishing Group, Inc.

Gulati, R. (1998). Alliances and networks. Strategic Management Journal, 19(4), 293-317. doi:10.1002/(SICI)1097-0266(199804)19:4<293::AID-SMJ982>3.0.CO;2-M, http://dx.doi.org/10.1002/(SICI)1097-0266(199804)19:4\%3C293::AID-SMJ982\%3E3.0.CO;2-M

Gulati, R., \& Gargiulo, M. (1999). Where do interorganizational networks come from? . American Journal of Sociology, 104(5), 1439-1493. doi:10.1086/210179, http://dx.doi.org/10.1086/210179

Gulati, R., \& Kletter, D. (2005). Shrinking core, expanding periphery: The relational architecture of high performing organizations. California Management Review, 47(3), 77-104.

Gulati, R., Nohria, N., \& Zaheer, A. (2000). Strategic networks. Strategic Management Journal, 21(3), 203-215. doi:10.1002/(SICI)1097-0266(200003)21:3<203::AID-SMJ102>3.0.CO;2-K, http://dx.doi.org/10.1002/(SICI)1097-0266(200003)21:3\%3C203::AID-SMJ102\%3E3.0.CO;2-K

Gulati, R., Sawhney, M., \& Paoni, A. (2002). Kellogg on technology and innovation. New Jersey: Wiley \& Sons.

Gupta, A. K., Tesluk, P. E., \& Taylor, S. M. (2007). Innovation at and across multiple levels of analysis. Organization Science, 18(6), 889-897. doi:10.1287/orsc.1070.0337, http://dx.doi.org/10.1287/orsc.1070.0337

Hamel, G., \& Getz, G. (2004 ). Funding growth in an age of austerity. Harvard Business Review, 82(7-8), 76-84.

Hamel, G., \& Prahalad, C. K. (2002). Competing for the future. New Delhi: Tata McGraw Hill Edition.

Hansen, M. T., \& Birkinshaw, J. (2007). The innovation value chain. Harvard Business Review, 85(6), 121-130.

Henderson, R., \& Cockburn, I. (1994). Measuring competence? Exploring firm effects in pharmaceutical research. Strategic Management Journal, 15, 63-84. doi:10.1002/smj.4250150906, http://dx.doi.org/10.1002/smj.4250150906

Henderson, R., \& Cockburn, I. (1996). Scale, scope, and spillovers: The determinants of research productivity in drug discovery. The RAND Journal of Economics, 27(1), 32-59. doi:10.2307/2555791, http://dx.doi.org/10.2307/2555791

Henderson, R., Jaffe, A. B., \& Trajtenberg, M. (1998). Universities as a source of commercial technology: A detailed analysis of university patenting, 1965 -1988. Review of Economics and Statistics, 80(1), 119-127. doi:10.1162/003465398557221, http://dx.doi.org/10.1162/003465398557221 
Henderson, R. M., \& Clark, K. B. (1990). Architectural innovation: The reconfiguration of existing product technologies and the failure of established firms. Administrative Science Quarterly, 35(1), 9-30. doi:10.2307/2393549, http://dx.doi.org/10.2307/2393549

Hoegl, M., \& Schulze, A. (2005). How to support knowledge creation in new product development: An investigation of knowledge management methods. European Management Journal, 23(3), 263-273. doi:10.1016/j.emj.2005.04.004, http://dx.doi.org/10.1016/j.emj.2005.04.004

Holsapple, C. W., \& Joshi, K. D. (2000). An investigation of factors that influence the management of knowledge in organizations. The Journal of Strategic Information Systems, 9(2-3), 235-261. doi:10.1016/S0963-8687(00)00046-9, http://dx.doi.org/10.1016/S0963-8687(00)00046-9

Holsapple, C. W., \& Joshi, K. D. (2002). Knowledge manipulation activities: Results of a delphi study. Information \& Management, $\quad 39(6), \quad 477-490 . \quad$ doi:10.1016/S0378-7206(01)00109-4, http://dx.doi.org/10.1016/S0378-7206(01)00109-4

Howell, J. M., \& Higgins, C. A. (1990). Champions of technological innovation. Administrative Science Quarterly, 35(2), 317-341. doi:10.2307/2393393, http://dx.doi.org/10.2307/2393393

Huber, G. P., \& Glick, W. H. (1993). Organizational change and redesign: ideas and insights for improving performance. New York: Oxford University Press.

Huygens, M., Van Den Bosh, F. A. J., Volberda, H. W., \& Baden-Fuller, C. (2001). Co-evolution of firm capabilities and industry competition: Investigating the music Industry. Organization Studies, 22(6), 791-1011. doi:10.1177/0170840601226004, http://dx.doi.org/10.1177/0170840601226004

Jaffe, A. B., Trajtenberg, M., \& Henderson, R. (1993). Geographic localization of knowledge spillovers as evidenced by patent citations. The Quarterly Journal of Economics, 108(3), 577-598. doi:10.2307/2118401, http://dx.doi.org/10.2307/2118401

Jansen, J., Vanden Bosch, F. A. J., \& Volberda, H. W. (2005a). Exploratory innovation, exploitive innovation and ambidexterity: The impact of environmental and organizational antecedents. Schmalenbach Business Review, 57, 351-363.

Jansen, J., Vanden Bosch, F. A. J., \& Volberda, H. W. (2005b). Managing potential and realized absorptive capacity: How do organizational antecedents matter? . Academy of Management Journal, 48(5), 999-1015. doi:10.5465/AMJ.2005.19573106, http://dx.doi.org/10.5465/AMJ.2005.19573106

Jansen, J., Vanden Bosch, F. A. J., \& Volberda, H. W. (2006). Exploratory innovation, exploitive innovation and performance: Effects of organizational antecedents and environmental moderators. Management Science, 52(11), 1661-1674. doi:10.1287/mnsc.1060.0576, http://dx.doi.org/10.1287/mnsc.1060.0576

Keats, B., \& Hitt, M. A. (1988). A causal model of linkages among environmental dimensions, macro organizational characteristics, and performance. Academy of Management Journal, 31(3), 570-598. doi:10.2307/256460, http://dx.doi.org/10.2307/256460

Kelm, K. M., Narayanan, V. K., \& Pinches, G. E. (1995). Shareholder value creation during R\&D innovation and commercialization stages. Academy of Management Journal, 38(3), 770-786. doi:10.2307/256745, http://dx.doi.org/10.2307/256745

Kirzner, I. M. (1997). Entrepreneurial discovery and the competitive market process: An Austrian approach. Journal of Economic Literature, 35(1), 60-85.

Klein, R., Rai, A., \& Straub, D. W. (2007). Competitive and cooperative positioning in supply chain logistics relationships. Decision Sciences, 38(4), 1-38. doi:10.1111/j.1540-5915.2007.00172.x, http://dx.doi.org/10.1111/j.1540-5915.2007.00172.x

Krackhardt, D. (2003). The strength of strong ties: The importance of philos in organization. In R. Cross, A. Parket \& L. Sasson (Eds.), Networks in the Knowledge Economy (pp. 82-105). New York: Oxford University Press.

Kwak, M. (2002). What's the best commercialization strategy for startups? . Sloan Management Review, 48(3), 10.

Lane, P. J., \& Lubatkin, M. (1998). Relative absorptive capacity and interorganizational learning. Strategic Management Journal, 19(5), 461-477. doi:10.1002/(SICI)1097-0266(199805)19:5<461::AID-SMJ953>3.0.CO;2-L, http://dx.doi.org/10.1002/(SICI)1097-0266(199805)19:5\%3C461::AID-SMJ953\%3E3.0.CO;2-L 
Lavie, D., \& Rosenkopf, L. (2006). Balancing exploration and exploitation in alliance formation. Academy of Management Journal, 49(4), 797-818. doi:10.5465/AMJ.2006.22083085, http://dx.doi.org/10.5465/AMJ.2006.22083085

Leonard-Barton, D. (1992). Core capabilities and core rigidities: A paradox in managing new product development. Strategic Management Journal, 13, 111-125. doi:10.1002/smj.4250131009, http://dx.doi.org/10.1002/smj.4250131009

Leonard-Barton, D. (1998). Wellsprings of knowledge: Building and sustaining the source of innovation. Cambrisde, MA: Harvard Business School Press.

Lerner, J. (1999). The Government as Venture Capitalist: The Long run impact of the SBIR program. The Journal of Business, 72(3), 285-318. doi:10.1086/209616, http://dx.doi.org/10.1086/209616

Levinthal, D. A. (1997). Adaptation on rugged landscapes. Management Science, 43(7), 934-950. doi:10.1287/mnsc.43.7.934, http://dx.doi.org/10.1287/mnsc.43.7.934

Levinthal, D. A., \& March, J. G. (1993). The myopia of learning. Strategic Management Journal, 14, 95-112. doi:10.1002/smj.4250141009, http://dx.doi.org/10.1002/smj.4250141009

Lewin, A. Y., \& Volberda, H. W. (1999). Prolegomena on coevolution: A framework for research on strategy and new organizational forms. Organization Science, 10(5), 519-534. doi:10.1287/orsc.10.5.519, http://dx.doi.org/10.1287/orsc.10.5.519

Lin, Y. C., Wang, L. C., \& Tserng, H. P. (2006). Enhancing knowledge exchange through web map-based knowledge management system in construction: Lessons learned in Taiwan. Automation in Construction 15(6), 693-705. doi:10.1016/j.autcon.2005.09.006, http://dx.doi.org/10.1016/j.autcon.2005.09.006

Lubatkin, M. H., Simsek, Z., \& Veiga, J. F. (2006). Ambidexterity and performance in small- to medium-sized firms: The pivotal role of top management team behavioral integration. Journal of Management, 32(5), 646-672. doi:10.1177/0149206306290712, http://dx.doi.org/10.1177/0149206306290712

MacCrimmon, K. R., \& Taylor, D. N. (1976). Decision making and problem solving In M. D. Dunnette (Ed.), Handbook of industrial and organizational psychology (pp. 1397-1453). Chicago: Rand McNally \& Co

March, J. G. (1991). Exploration and exploitation in organizational learning. Organization Science 2(1), 71-87. doi:10.1287/orsc.2.1.71, http://dx.doi.org/10.1287/orsc.2.1.71

Mata, F. J., Fuerst, W. L., \& Barney, J. B. (1995). Information technology and sustained competitive advantage: A resource-based analysis. MIS Quarterly, 19(4), 487-505. doi:10.2307/249630, http://dx.doi.org/10.2307/249630

McGrath, R. G., Tsai, M.-H., Venkataraman, S., \& MacMillan, I. C. (1996). Innovation, competitive advantage and rent: A model and test. Management Science, 42(3), 389-403. doi:10.1287/mnsc.42.3.389, http://dx.doi.org/10.1287/mnsc.42.3.389

Melville, N., Kraemer, K. L., \& Gurbaxani, V. (2004). Information technology and organizational performance: An integrative model of IT-business value. MIS Quarterly, 28(2), 283-322.

Miller, D., \& Friesen, P. H. (1983). Strategy-making and environment: The third link. Strategic Management Journal, 4(3), 221-235. doi:10.1002/smj.4250040304, http://dx.doi.org/10.1002/smj.4250040304

Milliken, F. J. (1987). Three types of perceived uncertainty about the environment: State, effect, and response uncertainty. Academy of Management Review, 12(1), 133-143.

Mitchell, W. (1989). Whether and when? Probability and timing of incumbents' entry into emerging industrial subfields. Administrative Science Quarterly, 34(2), 208-230. doi:10.2307/2989896, http://dx.doi.org/10.2307/2989896

Moore, G. A. (1991). Crossing the chasm. Marketing and selling disruptive products to mainstream customers. New-York: Harper Business.

Moore, G. A. (2000). Living on the fault line. Managing for shareholder value in the age of the Internet. New York: Harper Business.

Moore, J. F. (1993). Predators and prey: A new ecology of competition. Harvard Business Review, 71(3), 75-86.

Morita, A. (1992). Partnering for competitiveness: The role of Japanese business. Harvard Business Review, 70(3), 76.

Nahapiet, J., \& Ghoshal, S. (1998). Social capital, intellectual capital, and the organizational advantage. Academy of Management Review, 23(2), 242-266. 
Nambisan, S., \& Sawhney, M. (2007). A buyer's guide to the Innovation Bazar. Harvard Business Review, 85(6), 109-118.

Narayanan, V. K., Pinches, G. E., Kelm, K. M., \& Lander, D. M. (2000). The influence of voluntarily disclosed qualitative information. Strategic Management Journal, 21(7), 707-722. doi:10.1002/1097-0266(200007)21:7<707::AID-SMJ113>3.0.CO;2-A, http://dx.doi.org/10.1002/1097-0266(200007)21:7\%3C707::AID-SMJ113\%3E3.0.CO;2-A

Nerkar, A., \& Shane, S. (2007). Determinants of invention commercialization: An empirical examination of academically sourced inventions. Strategic Management Journal, 28(11), 1155-1166. doi:10.1002/smj.643, http://dx.doi.org/10.1002/smj.643

Nerkar, A. A., McGrath, R. G., \& MacMillan, I. C. (1996). Three facets of satisfaction and their influence on the performance of innovation teams. Journal of Business Venturing, 11(3), 167-188. doi:10.1016/0883-9026(96)00002-X, http://dx.doi.org/10.1016/0883-9026(96)00002-X

Nevens, T. M., Summe, G. L., \& Uttal, B. (1990). Commercializing technology: What do the best companies do? Harvard Business Review on Entrepreneurship (Vol. 1999, pp. 175). Cambridge, MA: Harvard Business School Press.

Newell, S., \& Clark, P. (1990). The importance of extra-organizational networks in the diffusion and appropriation of new technologies. Science Communication, 12(2), 199-212. doi:10.1177/107554709001200205, http://dx.doi.org/10.1177/107554709001200205

Newman, M. E. J. (2001). Scientific collaboration networks. II. Shortest paths, weighted networks, and centrality. Physical Review, 64(1), 1-7.

Newman, M. E. J. (2005). A measure of betweenness centrality based on random walks. Social Networks, 27(1), 39-54. doi:10.1016/j.socnet.2004.11.009, http://dx.doi.org/10.1016/j.socnet.2004.11.009

Nohria, N. (1992). Is a network perspective a useful way of studying organizations? In N. Nohria \& R. G. Eccles (Eds.), Networks and Organization: 287-301 Cambridge, MA: Harvard Business School Press.

Nohria, N., \& Eccles, R. G. (1992). Networks and organizations: Structure, form, and action. Cambridge, MA: Harvard Business School Press.

Numprasertchai, S., \& Igel, B. (2005). Managing knowledge through collaboration: Multiple case studies of managing research in university laboratories in Thailand. Technovation, 25(10), 1173-1182. doi:10.1016/j.technovation.2004.03.001, http://dx.doi.org/10.1016/j.technovation.2004.03.001

O’Reilly, C. A., \& Tushman, M. L. (2004). Ambidextrous organization. Harvard Business Review 82(4), 71-81.

Oliver, A. L. (2004). Biotechnology entrepreneurial scientists and their collaborations. Research Policy, 33(4), 583-597. doi:10.1016/j.respol.2004.01.010, http://dx.doi.org/10.1016/j.respol.2004.01.010

Pennings, J. M., \& Harianto, F. (1992). Technological networking and innovation implementation. Organization Science, 3(3), 356-382. doi:10.1287/orsc.3.3.356, http://dx.doi.org/10.1287/orsc.3.3.356

Pfeffer, J., \& Salancik, G. R. (1978). The external control of organizations: A resource dependence perspective. New York: Harper \& Row.

Pisano, G. P., \& Teece, D. J. (2007). How to capture value from innovation: Shaping intellectual property and industry architecture? California Management Review, 50(1), 278-296.

Podolny, J. M., \& Stewart, T. E. (1992). A role-based ecology of technological change. American Journal of Sociology, 100(5), 1224-1260. doi:10.1086/230637, http://dx.doi.org/10.1086/230637

Porter, M. E. (1998). Cluster and Competition: New agendas for firms, governments, and institutions. In M. E. Porter (Ed.), Michael Porter on competition: 213-308. Cambridge, MA: Harvard Business School Press.

Powell, W. W. (1998). Learning from collaboration: Knowledge and networks in the biotechnology and pharmaceutical industries. California Management Review, 40(3), 228-240.

Powell, W. W., Koput, K. W., \& Smith-Doerr, L. (1996). Interorganizational collaboration and the locus of innovation: Networks of learning in biotechnology. Administrative Science Quarterly, 41(1), 116-145. doi:10.2307/2393988, http://dx.doi.org/10.2307/2393988 
Provan, K. G., Fish, A., \& Sydow, J. (2007). Interorganizational networks at the network level: A review of empirical literature on whole networks. Journal of Management, 33(3), 479-516. doi:10.1177/0149206307302554, http://dx.doi.org/10.1177/0149206307302554

Raisch, S., \& Birkinshaw, J. (2008). Organizational ambidexterity: Antecedents outcomes and moderators. Journal of Management, 34(3), 275-409. doi:10.1177/0149206308316058, http://dx.doi.org/10.1177/0149206308316058

Rothaermel, F. T., \& Thursby, M. (2005). University-incubator firm knowledge flows: Assessing their impact on incubator firm performance. Research Policy, 34(3), 305-320. doi:10.1016/j.respol.2004.11.006, http://dx.doi.org/10.1016/j.respol.2004.11.006

Salamenkaita, J. P., \& Salo, P. (2002). Rationales for government interventions in the commercialization of new technologies. Technology Analysis and Strategic Management, 14(2), 183-200. doi:10.1080/09537320220133857, http://dx.doi.org/10.1080/09537320220133857

Salman, N., \& Saives, A.-L. (2005). Indirect networks: An intangible resource for biotechnology innovation. $R \& D$ Management, $\quad 35(2), \quad$ 203-215. doi:10.1111/j.1467-9310.2005.00383.x, http://dx.doi.org/10.1111/j.1467-9310.2005.00383.x

Scott, S. G., \& Bruce, R. A. (1994). Determinants of innovative behavior: A path model of individual innovation in the workplace. The Academy of Management Journal, 37(3), 580-607. doi:10.2307/256701, http://dx.doi.org/10.2307/256701

Shane, S. (2000). Prior knowledge and the discovery of entrepreneurial opportunities. Organization Science, 11(4), 448-469. doi:10.1287/orsc.11.4.448.14602, http://dx.doi.org/10.1287/orsc.11.4.448.14602

Sidhu, J., S, Commandeur, H., R, \& Volberda, H. W. (2007). The multifaceted nature of exploration and exploitation: Value of supply, demand, and spatial search for innovation. Organization Science, 18(1), 20-38. doi:10.1287/orsc.1060.0212, http://dx.doi.org/10.1287/orsc.1060.0212

Sidhu, J., S, Volberda, H. W., \& Commandeur, H., R (2004). Exploring exploration orientation and its determinants: Some empirical evidence. Journal of Management Studies, 41(6), 913-932. doi:10.1111/j.1467-6486.2004.00460.x, http://dx.doi.org/10.1111/j.1467-6486.2004.00460.x

Simsek, Z. (2009). Organizational ambidexterity: Towards a multilevel understanding. Journal of Management Studies, 46(4), 597-624. doi:10.1111/j.1467-6486.2009.00828.x, http://dx.doi.org/10.1111/j.1467-6486.2009.00828.x

Simsek, Z., Heavey, C., Veiga, J. F., \& Souder, D. (2009). Typology of aligning organizational ambidexterity's conceptualizations, antecedents and outcomes. Journal of Management Studies, 46(6), 864-894. doi:10.1111/j.1467-6486.2009.00841.x, http://dx.doi.org/10.1111/j.1467-6486.2009.00841.x

Sorensen, J. B., \& Stuart, T., E (2000). Aging, obsolescence, and organizational innovation. Administrative Science Quarterly, 45(1), 81-112. doi:10.2307/2666980, http://dx.doi.org/10.2307/2666980

Teece, D. J. (1986). Profiting from technological innovation: Implication for integration, collaboration, licensing and public policy. Research Policy, 15(6), 285-305. doi:10.1016/0048-7333(86)90027-2, http://dx.doi.org/10.1016/0048-7333(86)90027-2

Teece, D. J., Pisano, G., \& Shuen, A. (1997). Dynamic capabilities and strategic management. Strategic Management Journal, 18(7), 509-533. doi:10.1002/(SICI)1097-0266(199708)18:7<509::AID-SMJ882>3.0.CO;2-Z, http://dx.doi.org/10.1002/(SICI)1097-0266(199708)18:7\%3C509::AID-SMJ882\%3E3.0.CO;2-Z

Tushman, M. L. (1977). Special boundary roles in the innovation process. Administrative Science Quarterly, 22, 587-605. doi:10.2307/2392402, http://dx.doi.org/10.2307/2392402

Tushman, M. L., \& O'Reilly, C. A. (1996). Ambidextrous organizations: Managing evolutionary and revolutionary change. California Management Review, 38(4), 8-30.

Tushman, M. L., \& O'Reilly, C. A. (2002). Winning through innovation: A practical guide to leading organizational change and renewal. Boston, MA: Harvard Business School Press.

Van den Bosch, F. A. J., Volberda, H. W., \& Boer, M. d. (1999). Coevolution of firm absorptive capacity and knowledge environment: Organizational forms and combinative capabilities. Organization Science, 10(5), 551-568. doi:10.1287/orsc.10.5.551, http://dx.doi.org/10.1287/orsc.10.5.551

Van Wijk, R. (2003). Organizing Knowledge in Internal Networks. Erasmus Research Institute of Management, Erasmus University. 
Veugelers, R. (1997). Internal R\&D expenditures and external technology sourcing. Research Policy, 26, 303-315. doi:10.1016/S0048-7333(97)00019-X, http://dx.doi.org/10.1016/S0048-7333(97)00019-X

Vintergaard, C. (2005). Opportunities in corporate venturing-actors creating passageways. International Journal of Innovation Management, 9(2), 215-239. doi:10.1142/S1363919605001241, http://dx.doi.org/10.1142/S1363919605001241

Volberda, H. W. (1996). Toward the flexible form: How to remain vital in hypercompetitive environments. Organization Science, 7(4), 359-374. doi:10.1287/orsc.7.4.359, http://dx.doi.org/10.1287/orsc.7.4.359

Volberda, H. W. (1998). Building the flexible firm: How to remain competitive. New York: Oxford University Press.

Volberda, H. W., \& Lewin, A. Y. (2003). Co-evolutionary dynamics within and between firms: From evolution to co-evolution. Journal of Management Studies, 40(8), 2105-2130. doi:10.1046/j.1467-6486.2003.00414.x, http://dx.doi.org/10.1046/j.1467-6486.2003.00414.x

Wade, J. (1996). A community-level analysis of sources and rates of technological variation in the microprocessor market. The Academy of Management Journal, 39(5), 1218-1244. doi:10.2307/256997, http://dx.doi.org/10.2307/256997

Wade, M., \& Hulland, J. (2004). The resource based view and information systems research: Review, extension, suggestions for future research. MIS Quarterly, 28(1), 107-142.

Wallsten, S. J. (2000). The effects of government-industry R\&D programs on private R\&D: The case of the small business innovation research program. The RAND Journal of Economics, 31(1), 82-100. doi:10.2307/2601030, http://dx.doi.org/10.2307/2601030

Wasserman, S., \& Faust, K. (1994). Social network analysis: Methods and applications. Cambridge, UK: Cambridge University Press.

Wielemaker, M. (2003). Managing initiatives: A synthesis of the conditioning and knowledge-creating view. Erasmus University Rotterdam.

Williamson, O. E. (1991). Comparative economic organization: The analysis of discrete structural alternatives. Administrative Science Quarterly, 36(2), 269-296. doi:10.2307/2393356, http://dx.doi.org/10.2307/2393356

Zack, M. H. (1999). Developing a knowledge stratregy. California Management Review, 41(3), 125-145.

Zack, M. H. (2003). Rethinking knowledge based organization. Sloan Management Review, 44(4), 12-17.

Zahra, S. A., \& George, G. (2002). Absorptive capacity: A review, reconceptualization, and extension. Academy of Management Review, 27(2), 185-203.

Zahra, S. A., \& Nielsen, A. P. (2002). Sources of capabilities, integration and technology commercialization. Strategic Management Journal, 23(5), 377-398. doi:10.1002/smj.229, http://dx.doi.org/10.1002/smj.229 
Table 1. Definitions of the Constructs

\begin{tabular}{|c|c|l|}
\hline Construct name & Type & \multicolumn{1}{c|}{ Definition } \\
\hline $\begin{array}{c}\text { Ability to } \\
\text { Commercialize } \\
\text { Innovations }\end{array}$ & $\begin{array}{c}\text { Dependent } \\
\text { Variable }\end{array}$ & $\begin{array}{l}\text { A firm's capacity to bring a product or service into a market and reach } \\
\text { the mainstream of the market beyond the initial adopters. There are } \\
\text { three aspects to our definition (a) recognize a market for an } \\
\text { innovation, (b) develop the products and (c) sell/distribute the product. } \\
\text { While the last two can be outsourced, the first one cannot. }\end{array}$ \\
\hline $\begin{array}{c}\text { Networks and Resources } \\
\text { Ambidexterity }\end{array}$ & $\begin{array}{c}\text { Independent } \\
\text { Variable } \\
\text { between organizations, and between organizations and innovation } \\
\text { engines. }\end{array}$ \\
\hline $\begin{array}{c}\text { Absorptive Capacity } \\
\text { and exploitation. }\end{array}$ \\
\hline $\begin{array}{c}\text { Environmental } \\
\text { Turbulence }\end{array}$ & Mediator & $\begin{array}{l}\text { The limit to the rate at which a firm can absorb scientific or } \\
\text { technological information and/or a limit to the quantity of such } \\
\text { information that can be absorbed. }\end{array}$ \\
\hline $\begin{array}{c}\text { Environmental } \\
\text { Munificence }\end{array}$ & Moderator & $\begin{array}{l}\text { The level of uncertainty and unpredictability in the firm's environment } \\
\text { sustained growth. }\end{array}$ \\
\hline $\begin{array}{c}\text { Environmental } \\
\text { Complexity }\end{array}$ & Moderator & $\begin{array}{l}\text { The extent to which a firm's environment has a wide range of firms in } \\
\text { its industry, high number of suppliers and customers, and/or a high } \\
\text { range of products of services. }\end{array}$ \\
\hline
\end{tabular}

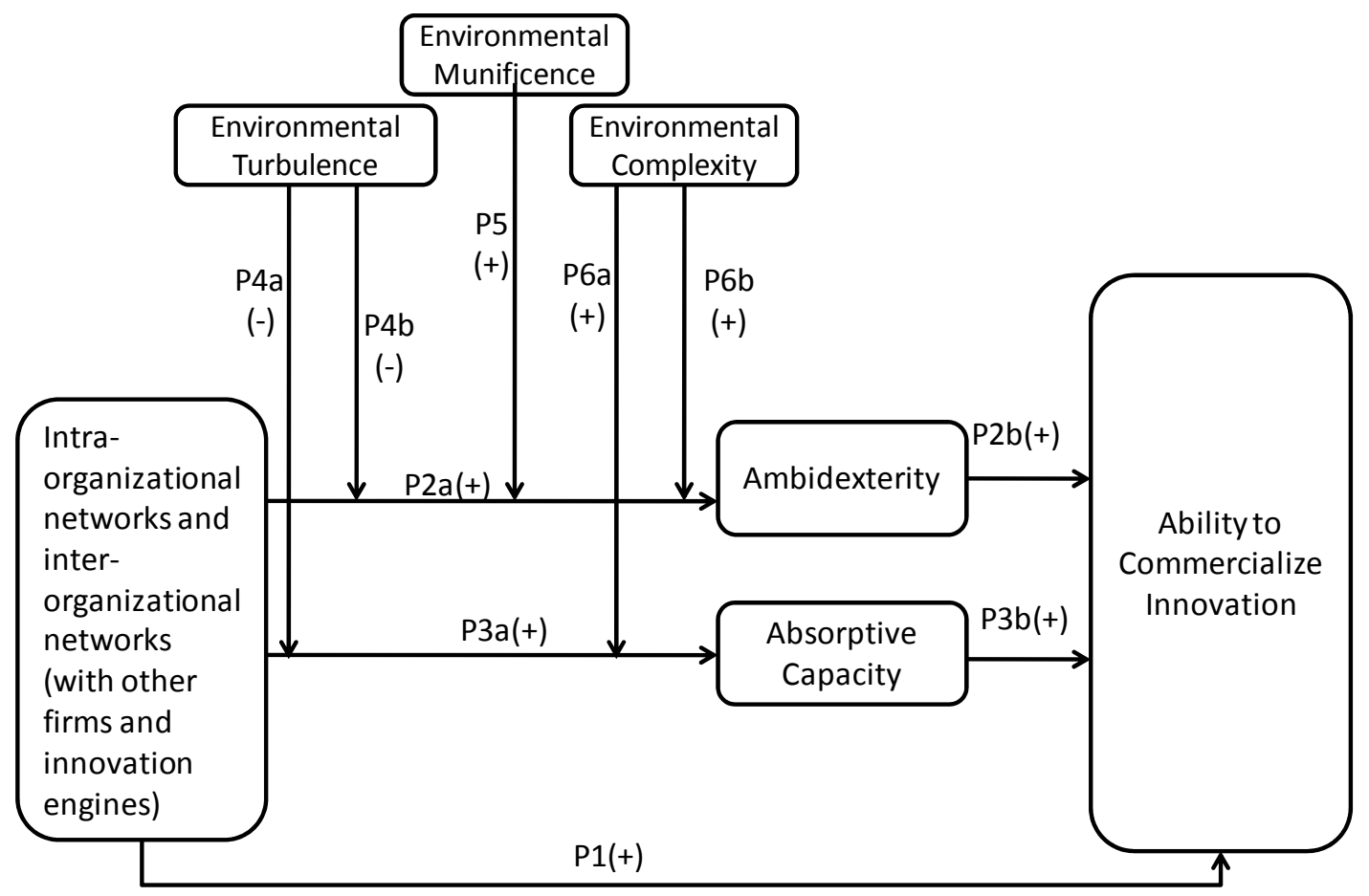

Figure1. An Integrative Model for Commercialization of innovation 